\title{
Brazilian agricultural research in the Web of Science: a bibliometric study of scientific output and collaboration (2000-2011)
}

\author{
Rosely Andrade Vargas \\ Mestra; Universidade Federal do Rio Grande do Sul (UFGRS), Porto Alegre, RS, Brasil; \\ rosely.vargas@telessauders.ufrgs.br \\ Samile Andréa de Souza Vanz \\ Doutora; Universidade Federal do Rio Grande do Sul (UFGRS), Porto Alegre, RS, Brasil; \\ samilevanz@terra.com.br \\ Ida Regina Chittó Stumpf \\ Doutora; Universidade Federal do Rio Grande do Sul (UFGRS), Porto Alegre, RS, Brasil; \\ irstumpf@ufrgs.br
}

\begin{abstract}
This paper presents an analysis of the scientific output and collaboration of Brazilian agricultural research in the Web of Science (WoS) during 2000-2011. A total of 45,163 documents were retrieved. Data analysis was conducted with the use of the softwares Bibexcel and Pajek. The results indicated that the number of Brazilian articles in the field of agricultural sciences indexed in WoS has increased by $344 \%$; however, the main driver for this growth was the raise in the number of national journals indexed in the database. Although Brazilian articles have been found in 799 journals from 46 countries, 53.5\% of the total production was published in national journals with low impact factor. The percentage of articles with multiple authors in the total volume of publications increased from $96.1 \%$ in 2000 to $98.4 \%$ in 2011 . The proportion of articles in collaboration between institutions rose from $47.3 \%$, in 2000 , to $64.2 \%$, in 2011. However, there was a decrease in publications with international collaboration from $21.7 \%$ in 2000 to $15.4 \%$ in 2011. The most important collaborative relationships were established with the U.S., France and Germany.
\end{abstract}

Keywords: Brazilian science. Agricultural sciences. Scientific output. Bibliometrics. Scientific collaboration.

\section{Introduction}

Brazil is amongst the world's largest food producers, having its economy based on the agricultural sector. Agriculture, including the long agribusiness chain, accounts for about $30 \%$ of the national Gross Domestic Product (GDP). This performance is partly due to the agricultural research, which has gained impetus 
in the country in the past fifty years - first, with the creation of graduate courses in agricultural sciences and, then, with the establishment of the Empresa Brasileira de Pesquisa Agropecuária (Embrapa) - the Brazilian Company of Agricultural Research. Embrapa is a public enterprise devoted to provide feasible solutions to agribusiness through generating and transferring knowledge and technology.

Presently, most of the agricultural research developed in Brazil is conducted at 42 local branches of Embrapa, 613 graduate courses and over 30 state research institutes (GEOCAPES, 2013; EMPRESA BRASILEIRA..., 2013). About $10 \%$ of the Brazilian government public expenditure on Research and Development (R\&D) are oriented towards agriculture (MINISTÉRIO..., 2013). This is one of the activities that amass the largest volume of governmental resources aimed at research (CRUZ; CHAIMOVICH, 2010). The relevance of agricultural research lies in its both economic and social effects: it raises the productivity of agribusiness, promotes exports and creates jobs, thus contributing to the growth of the GDP and the rural development of the country.

Measured in terms of number of indexed articles published, agricultural research stands out as one of the most productive fields within the Brazilian scientific output (GLÄNZEL; LETA; THIJS, 2006). It is also one of the fields in which the country has the most significant worldwide representation. Between 2007 and 2011, the articles on agricultural sciences published by Brazilian researchers in journals indexed in the Web of Science (WoS) corresponded to $8.8 \%$ of the world output (ADAMS; PENDLEBURY; STEMBRIDGE, 2013). The bulk of articles in this area led Brazil to stand at the 13th position of WoS' international ranking of scientific output: ahead of countries like the Netherlands, Russia, Switzerland and Denmark (PACKER, 2011).

This article analyses Brazilian output in agricultural sciences as represented in WoS in the period from 2000 to 2011. Some trends were observed in relation to productivity, languages, chosen journals and to collaboration among authors, institutions and countries. Throughout these 12 years, graduate teaching in this particular knowledge field has expanded in the country. There was also a substantial rise in the collection of national scientific journals indexed in the 
Thomson Reuters' database, as well as a process of change in the journals. Bibliometric analysis show the impact of such changes in the Brazilian output in agricultural sciences.

\section{Methods}

The choice of WoS for data collection was based on its tradition and comprehensiveness, as well as for being internationally used for macro analyses of scientific output. We considered also the fact that it includes the names of all authors of published works, and information on the institutions and country of origin of the authors as well, thus allowing analyses of collaboration patterns.

Data retrieval was based on keywords selected from a list of knowledge areas and subareas, as defined by the Coordenação de Aperfeiçoamento de Pessoal de Nível Superior (CAPES), and adapted to the Web of Science Category, which contains 249 terms for the various knowledge areas and subareas. Out of these, we selected 13 terms related to the Brazilian agricultural sciences, including agronomy, food and technology, veterinary science and fishery resources. The term search included the WC (Web of Science Category) field coupled with a CU (country) field, referring to the authors' country of residence. The term search used was: $\mathrm{CU}=(\mathrm{BRAZIL}$ OR BRASIL) AND WC=(Agricultural Economics \& Policy OR Agricultural Engineering OR Agriculture, Dairy \& Animal Science OR Agriculture, Multidisciplinary OR Agronomy OR Fisheries OR Food Science \& Technology OR Forestry OR Horticulture OR Plant Sciences OR Soil Science OR Veterinary Sciences OR Zoology).

Data retrieval was done in January 2012 through the Advanced Search at the Science Citation Index Expanded (SCI-EXPANDED) and at the Social Sciences Citation Index (SSCI). It was limited to the period 2000-2011 and to scientific articles. A total of 45,163 articles with at least one Brazilian address in the field Author Address were retrieved. The softwares Bibexcel, Excel 2007 and Pajek were used for data and network analysis.

For the analyses of institutions and countries, we used the whole count method - broadly applied in bibliometric studies -, which attributes the value of 
Rosely Andrade Vargas, Samile Andréa de Souza Vanz, Ida Regina Chittó Stumpf

an article for each of the several participants (LUUKKONEN; PERSSON; SIVERTSEN, 1992; BORDONS; GOMEZ, 2000). Therefore, for an article authored, for instance, by five different institutions, the value of one article was attributed to each institution. The same procedure was followed for counting articles of distinct countries.

\section{Results and discussion}

Between 2000 and 2011, Brazilian publications in agricultural sciences indexed in $\mathrm{WoS}$, grew by $344.1 \%$ (from 1,546 items to 6,866 items) (Table 1). The greatest growth rates were observed in 2003 (19.2\%), 2007 (52.4\%) and 2008 (32.6\%). The $344.1 \%$ growth was higher than the increase of $217.2 \%$ in the number of publications in Brazil, considering all areas of knowledge in WoS.

Table 1 - Growth in the number of Brazilian papers per year in agricultural sciences in WoS 2000-2011

\begin{tabular}{lllllll}
\hline & \multicolumn{2}{c}{ Agricultural Science } & \multicolumn{2}{c}{ Other Fields } & \multicolumn{2}{c}{ Total Brazil } \\
\hline Year & $\mathrm{N}^{\mathrm{o}}$ papers & Growth $\%$ & $\mathrm{~N}^{\mathrm{o}}$ papers & Growth $\%$ & $\mathrm{~N}^{\mathrm{o}}$ papers & Growth \% \\
\hline 2000 & 1546 & -- & 9293 & -- & 10839 & - \\
2001 & 1511 & -2.3 & 9957 & 7.1 & 11468 & 5.8 \\
2002 & 1710 & 13.2 & 11101 & 11.5 & 12811 & 11.7 \\
2003 & 2039 & 19.2 & 11767 & 6.0 & 13806 & 7.8 \\
2004 & 2276 & 11.6 & 13664 & 16.1 & 15940 & 15.5 \\
2005 & 2607 & 14.5 & 14342 & 5.0 & 16949 & 6.3 \\
2006 & 2980 & 14.3 & 15945 & 11.2 & 18925 & 11.7 \\
2007 & 4541 & 52.4 & 18809 & 18.0 & 23350 & 23.4 \\
2008 & 6022 & 32.6 & 22303 & 18.6 & 28325 & 21.3 \\
2009 & 6481 & 7.6 & 23726 & 6.4 & 30207 & 6.6 \\
2010 & 6584 & 1.6 & 25267 & 6.5 & 31851 & 5.4 \\
2011 & 6866 & 4.3 & 27520 & 8.9 & 34386 & 8.0 \\
\hline Total & 45163 & 344.1 & 203694 & 196.1 & 248857 & 217.2 \\
\hline \multicolumn{5}{r}{}
\end{tabular}

Two main factors were behind the growth indicated in Table 1. The first one was the increase in the number of Brazilian journals indexed in WoS (TESTA, 2011). The second was the expansion of graduate programs in this area (MEIS; ARRUDA; GUIMARÃES, 2007; ADAMS; KING, 2009). 
Rosely Andrade Vargas, Samile Andréa de Souza Vanz, Ida Regina Chittó Stumpf

The collection of Brazilian journals indexed in WoS accounted to only 17 titles in 2000 (TARGINO; GARCIA, 2000). In 2010, the collection had expanded to 132 titles, an increase of $676.5 \%$ brought about by the process of "globalization" of the database (TESTA, 2011). In what concerns agricultural sciences, the expansion amounted to $462.5 \%$. At the beginning of the decade, WoS indexed eight Brazilian journals in the category Agriculture, Biology \& Environmental Sciences (ABES). In 2010, there were 45 titles in this category.

The indexation in that database seems to have encouraged changes in the main Brazilian journals in the area of agricultural sciences. Following indexation, ten journals widely used for scholarly publishing in the area either reduced periodicity or started to publish special issues. The increase in the number of issues published annually by these journals has provided Brazilian researchers with further publishing space and helped to enhance the number of articles from Brazil indexed in WoS (VARGAS; VANZ; STUMPF, 2014).

As to graduate programs in agricultural sciences in the country, their number grew $96.5 \%$, from 172 in 2000 to 338 in 2011. In this same period, the annual number of $\mathrm{PhDs}$ and Masters graduates in the country increased by $171 \%$ and 124\%, respectively (GEOCAPES, 2013). In Brazil, research activities are developed mainly within public universities and research institutes (CRUZ; CHAIMOVICH, 2010). Thus, according to Meis, Arruda and Guimarães (2007), "there is a linear correlation" between the number of $\mathrm{PhD}$ graduates and the number of articles published in WoS.

The contribution of the agricultural sciences in the whole of Brazilian scientific output in the studied database rose from $14.3 \%$ in 2000 to $20.0 \%$ in 2011 (Figure 1). 
Rosely Andrade Vargas, Samile Andréa de Souza Vanz, Ida Regina Chittó Stumpf

Figure 1 - Percentage of publications on agricultural sciences in the total Brazilian scientific output indexed in WoS, 2000-2011

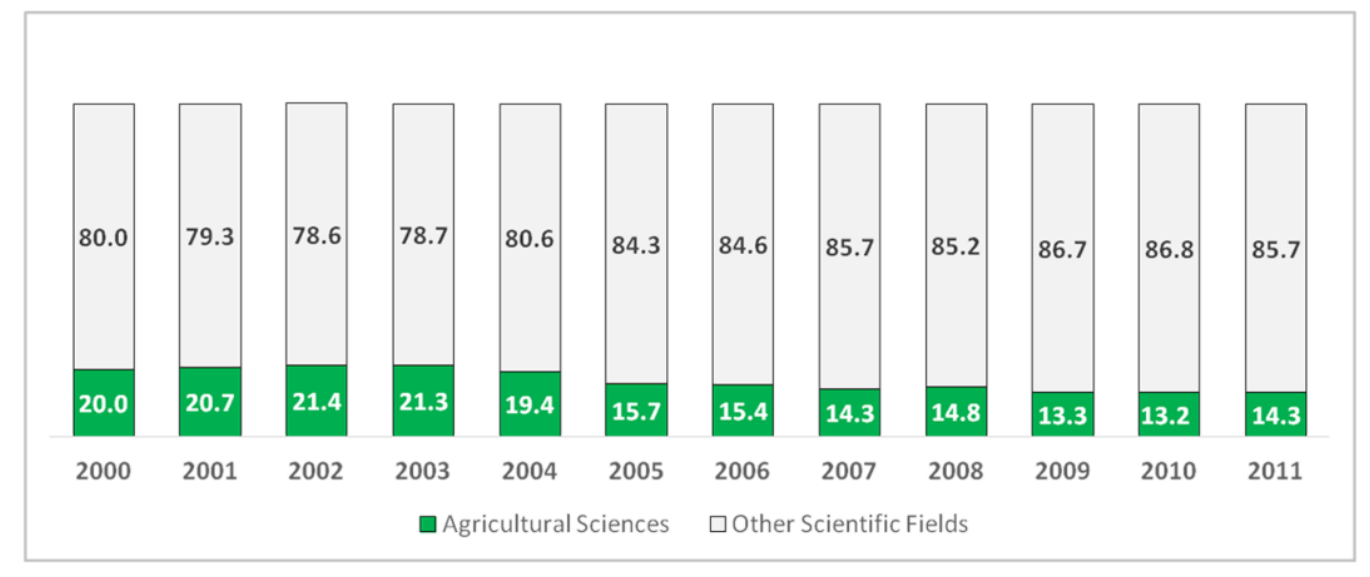

Source: research data.

The growth in the number of articles by Brazilian authors in WoS' category of agricultural sciences follows the trends observed in previous studies (LETA; THIJS; GLÄNZEL, 2013; LYRA; GUIMARÃES, 2007). Since the 1990s, this scientific field stands as one of the most productive in the country in terms of papers indexed in WoS (GLÄNZEL; LETA; THIJS, 2006). In areas such as agronomy, veterinary science, microbiology, and sciences of plants and animals, it is also observed a predominance of articles originated in Brazil in the whole world output (ADAMS; KING, 2009; CRUZ; CHAIMOVICH, 2010).

The data collected by the present study show that between 2000 and 2011 most of the Brazilian scientific output in the area of agricultural sciences was published in Brazilian journals. Although articles by Brazilian authors in this area have been found in 799 journals published in 46 distinct countries, 24,180 articles (53.5\%) were published in Portuguese, in national journals, with limited impact factor and, therefore, lower visibility.

Among the twenty most used journals to publish Brazilian papers, which together have published 21,916 (48.5\%) articles, only two are edited outside Brazil: Zootaxa, from New Zealand, and Veterinary Parasitology, from the Netherlands (Table 2). All of the others are non-profit domestic publications whose publishers are either scientific societies, universities or public institu- 
Rosely Andrade Vargas, Samile Andréa de Souza Vanz, Ida Regina Chittó Stumpf

tions. Two of the journals listed in Table 2 do not appear in the JCR Science Edition 2012. Thus, their impact factor was not presented, they are: Revista Brasileira de Zootecnia, published by the Sociedade Brasileira de Zootecnia and which amassed most of the articles, and Planta Daninha, published by the Sociedade Brasileira da Ciência das Plantas Daninhas. Both have been excluded from JCR "[...] because they presented atypical citation standards which lead to misrepresentation in their impact factors [...]" (JOURNAL CITATION REPORTS, 2012). Nevertheless, both journals remain indexed in WoS.

Table 2 - Journals with the largest number of Brazilian papers in agricultural sciences in WoS 2000-2011

\begin{tabular}{lrrlr}
\hline & & & Journal \\
Journal & Total articles & $\%$ & Country & IF \\
\hline Revista Brasileira de Zootecnia & 3,235 & 7.2 & Brazil & - \\
Pesquisa Agropecuária Brasileira & 2,534 & 5.6 & Brazil & 0.661 \\
Arquivo Brasileiro de Medicina & & & & \\
Veterinária e Zootecnia & 2,085 & 4.6 & Brazil & 0.269 \\
Ciência e Agrotecnologia & 1,843 & 4.0 & Brazil & 0.395 \\
Ciência Rural & 1,601 & 3.5 & Brazil & 0.383 \\
Revista Brasileira de Ciência do Solo & 1,415 & 3.1 & Brazil & 0.733 \\
Zootaxa & 1,205 & 2.8 New Zealand & 0.974 \\
Pesquisa Veterinária Brasileira & 890 & 2.0 & Brazil & 0.538 \\
Revista Brasileira de Fruticultura & 874 & 1.9 & Brazil & 0.296 \\
Revista Brasileira de Zoologia/Zoologia (1) & 858 & 1.9 & Brazil & 0.658 \\
Ciência e Tecnologia de Alimentos & 788 & 1.7 & Brazil & 0.326 \\
Scientia Agricola & 673 & 1.5 & Brazil & 0.796 \\
Semina-Ciências Agrárias & 575 & 1.3 & Brazil & 0.301 \\
Planta Daninha & 548 & 1.2 & Brazil & - \\
Veterinary Parasitology & 537 & 1.2 & Netherlands & 2381 \\
Horticultura Brasileira & 489 & 1.1 & Brazil & 0.513 \\
Revista Árvore & 467 & 1.0 & Brazil & 0.327 \\
Revista Ciência Agronômica & 458 & 1.0 & Brazil & 0.713 \\
Acta Botanica Brasilica & 440 & 1.0 & Brazil & 0.374 \\
Bioscience Journal & 401 & 0.9 & Brazil & 0.275 \\
\hline Subtotal & 21,916 & 48.5 & & \\
\hline 729 Other Journals & 23,247 & 51.5 & & \\
\hline Total & $\mathbf{4 5 , 1 6 3}$ & $\mathbf{1 0 0 . 0}$ & & \\
\hline
\end{tabular}

(1)Since its foundation in 1982, were published under the name Revista Brasileira de Zoologia. With the goal of broadening its international visibility, starting in 2009, it began to be called Zoologia while keeping the original volume and issue numbering. 

bibliometric study of scientific output and collaboration (2000-2011)

Rosely Andrade Vargas, Samile Andréa de Souza Vanz, Ida Regina Chittó Stumpf

Concentrating output in Brazilian journals had impact on the languages most used for publications in the researched area. Articles written in English accounted to 25,730 (57.0\%); papers in Portuguese totaled 18,964 (42.0\%). The use of other languages was restricted to only 469 papers (1.0\%). The predominance of English can be explained by both the international prominence this language assigns to publications (MEADOWS, 1999) and the source chosen for this research, which gathers mainly journals edited in English in the United States, England and Netherlands (VAN LEEUWEN et al., 2001).

English was the main language of publication between 2000 and 2007. In 2008, the percentage of articles written in Portuguese exceeded that of papers in English due to the entry of a large number of Brazilian journals in WoS. In 2010 English featured again as the preferred language (Figure 2).

Figure 2 - Percentage of Brazilian papers in agricultural sciences by language indexed in WoS 2000-2011

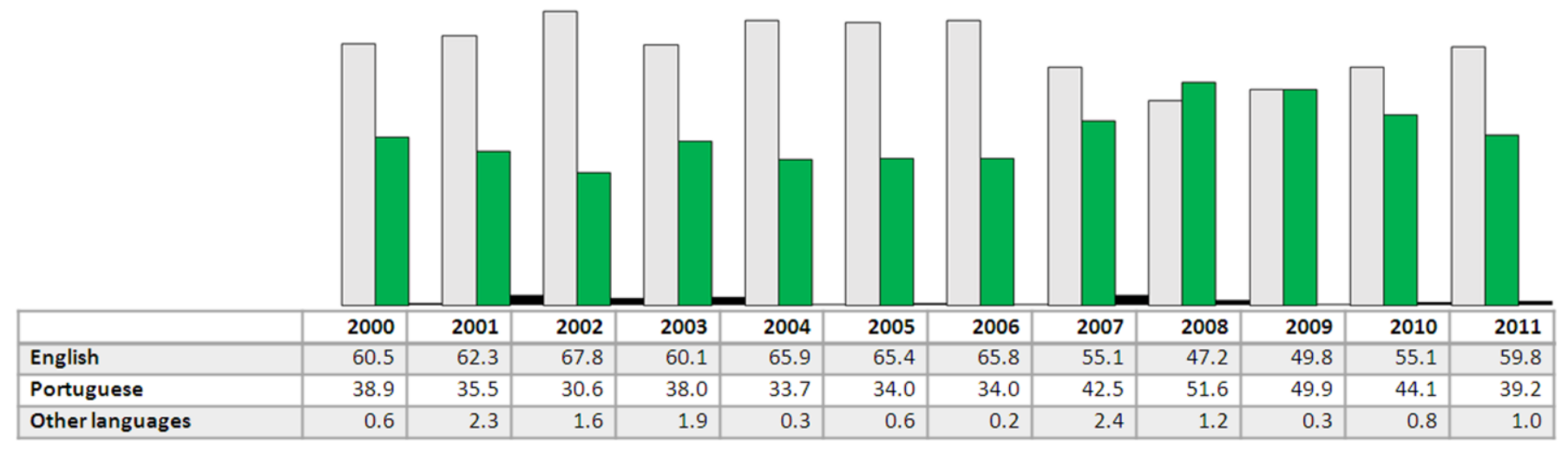

Source: research data.

The percentage of papers published in Portuguese $-40.0 \%$ in average during the period 2000-2011 - is significant. It demonstrates the preference of Brazilian researchers to disseminate their work in the national language and in domestic periodicals. Arvanitis and Chatelin (1984) as well as Velho (1986) had already observed this peculiarity. According to these authors, the agricultural sciences research agenda, marked by a domestic, local and multidisciplinary character, affects the selection of publishing channels and of the target public. 
Rosely Andrade Vargas, Samile Andréa de Souza Vanz, Ida Regina Chittó Stumpf

This custom is also observed in other knowledge areas. Meneghini and Packer (2007) estimate that about $60 \%$ of the 50,000 papers published annually by researches from Brazil are written in Portuguese and aimed at national journals, what ends up reducing visibility of the Brazilian scientific output.

Among the documents analyzed, we identified 5,910 Brazilian and foreign organizations to which the authors are connected. However, a small group of 18 organizations, all of them constituting public institutions, concentrated $50.3 \%$ of the whole collection of papers (Table 3). Among the most productive institutions there are two public enterprises devoted to research: Embrapa, which directs the national system of agricultural research and has branches virtually all over the country; and APTA, a public enterprise set up by the São Paulo State government and which congregates traditional institutes such as the Instituto Agronômico de Campinas (Agronomic Institute of Campinas), created in the 19th century. All the other positions in the ranking of the most productive institutions are occupied by public universities, mainly Universidade de São Paulo (USP) and Universidade Estadual Paulista Julio de Mesquita Filho (UNESP), both of which in the past decades have accounted for a major part of the Brazilian publications indexed in WoS (VELLOSO; LANNES; MEIS, 2004).

Table 3 - Institutions with major output in agricultural sciences in WoS 2000-2011

\begin{tabular}{lrr}
\hline Institution & $\mathbf{N}^{\mathbf{0}}$ of papers & \% \\
\hline Universidade de São Paulo (USP) & 7,134 & 8.1 \\
Universidade Estadual Paulista Julio de Mesquita Filho (Unesp) & 6,060 & 6.8 \\
Empresa Brasileira de Pesquisa Agropecuária (Embrapa) & 5,449 & 6.2 \\
Universidade Federal de Viçosa (UFV) & 3,899 & 4.4 \\
Universidade Federal de Lavras (UFLA) & 2,568 & 2.9 \\
Universidade Federal do Rio Grande do Sul (UFRGS) & 2,560 & 2.9 \\
Universidade Estadual de Campinas (UNICAMP) & 2,362 & 2.7 \\
Universidade Federal de Minas Gerais (UFMG) & 2,108 & 2.4 \\
Universidade Federal de Santa Maria (UFSM) & 1,843 & 2.1 \\
Universidade Federal do Rio de Janeiro (UFRJ) & 1,558 & 1.8 \\
Universidade Federal do Paraná (UFPR) & 1,417 & 1.6 \\
Agência Paulista de Tecnologia dos Agronegócios (APTA) & 1,294 & 1.5 \\
Universidade Estadual de Maringa (UEM) & 1,224 & 1.4 \\
Universidade de Brasília (UNB) & 1,053 & 1.2 \\
Universidade Federal Rural Rio de Janeiro (UFRRJ) & 1,044 & 1.2 \\
Universidade Federal Rural Pernambuco (UFRPE) & 1,037 & 1.2 \\
Universidade Federal do Ceará (UFC) & 992 & 1.1 \\
Universidade Estadual de Londrina (UEL) & 963 & 1.1
\end{tabular}


Rosely Andrade Vargas, Samile Andréa de Souza Vanz, Ida Regina Chittó Stumpf

Subtotal for the 18 institutions

$44,565 \quad 50.3$

TOTAL

$43,995 \quad 49.7$
$88560 \quad 100$

Source: research data.

Scientific collaboration, examined through coauthorship of the publications extracted from WoS, proved to be high among researchers: 44,141 papers (97.7\%) involved multiple authorship. The average number of authors per article, which was 4.1 in 2000 , rose to 5.0 in 2011 . This can be related to the expansion of graduate courses. In recent years there was an increase in the number of graduate students and research groups in the universities, and the academics, who comprise the majority of researchers in the country, have written more papers with their advised graduate students (VANZ; STUMPF, 2012).

Another likely contributing factor to the increase in coauthorship is the criteria for evaluating graduate programs in Brazil. The system, which was set up by CAPES in the end of the 1990s, includes quantitative performance indicators, such as the number of papers published annually. Jointly produced papers help researchers to expand their scientific output (LEITE; LETA; MUGNAINI, 2011).

Table 4 - Evolution of collaboration between agricultural sciences researchers 2000-2011

\begin{tabular}{|c|c|c|c|c|c|c|c|c|c|c|c|c|}
\hline Year & 2000 & 2001 & 2002 & 2003 & 2004 & 2005 & 2006 & 2007 & 2008 & 2009 & 2010 & 2011 \\
\hline $\begin{array}{r}\text { Coauthored } \\
\text { papers }\end{array}$ & 1486 & 1464 & 1650 & 2000 & 2200 & 2528 & 2885 & 4430 & 5881 & 6373 & 6486 & 6758 \\
\hline Total n.of papers & 1546 & 1511 & 1710 & 2039 & 2276 & 2607 & 2980 & 4541 & 6022 & 6481 & 6584 & 6866 \\
\hline coauthored/total & 96.1 & 96.9 & 96.5 & 98.1 & 96.7 & 96.9 & 96.8 & 97.5 & 97.6 & 98.3 & 98.5 & 98.4 \\
\hline
\end{tabular}

Scientific collaboration between distinct institutions had a significant increment in the period 2000-2011. The number of papers involving interinstitutional coauthorship, including Brazilian and foreign institutions, rose 501.9\% from 732 articles in 2000 to 4,406 in 2011. Thus, the proportion of scientific 
Rosely Andrade Vargas, Samile Andréa de Souza Vanz, Ida Regina Chittó Stumpf

output coauthored between two or more institutions grew from $47.3 \%$ of the total papers in 2000 to $64.2 \%$ in 2011 . The number of coauthored papers from a single institution is less representative, though also experienced a growth of $203.8 \%$, from 807 papers in 2000 to 2,452 in 2011. 

bibliometric study of scientific output and collaboration

Rosely Andrade Vargas, Samile Andréa de Souza Vanz, Ida Regina Chittó Stumpf

Figure 3 - Number of Brazilian articles in agricultural sciences in WoS with and without interinstitutional collaboration, 2000-2011

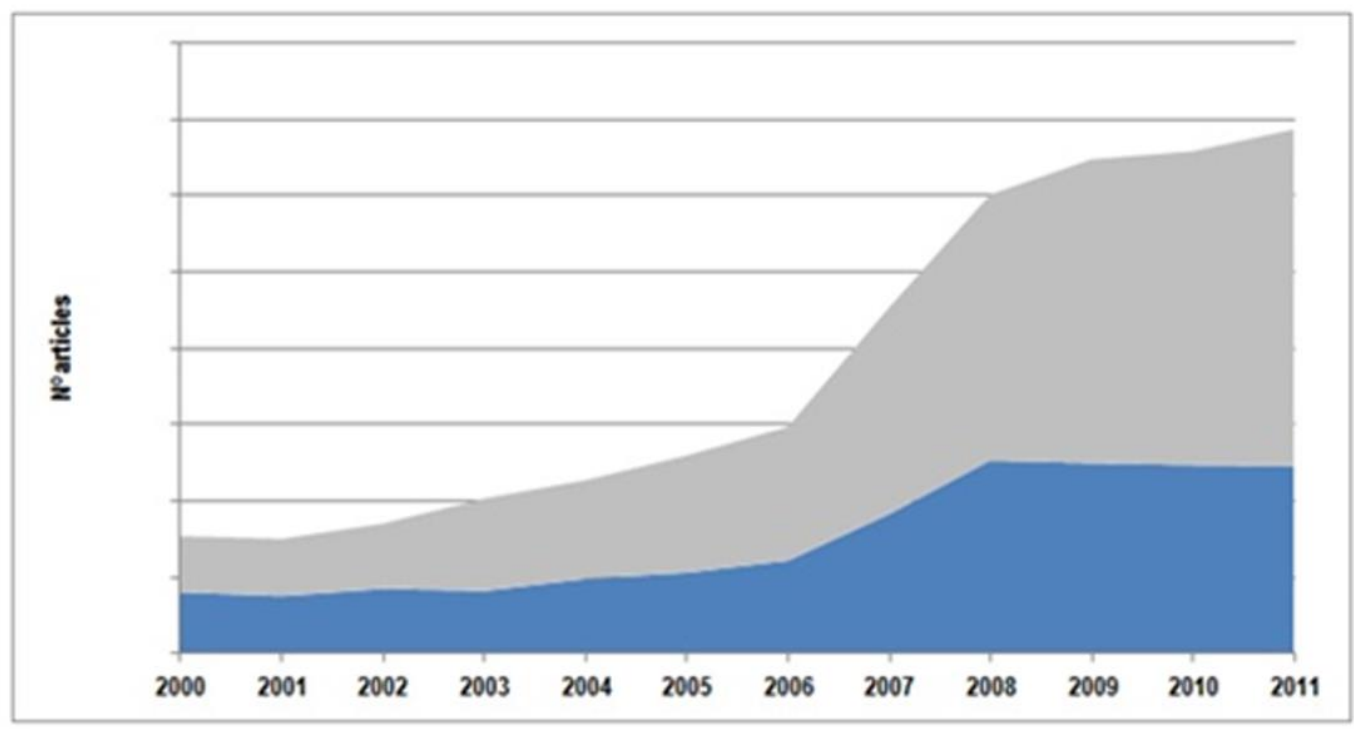

Source: research data.

The analyses confirmed a tendency on the part of Brazilian scientific production towards increasing interinstitutional collaboration. In the past two decades, public policies were implemented aiming to promote the creation of cooperative networks between universities, research institutes and other organizations. The funding agencies that award grants to universities and research institutes have also encouraged partnerships (MENEGHINI, 1996; LETA; CHAIMOVICH, 2002).

The national institutions that presented the highest volume of publications stand out as well on the development of cooperative research projects. By means of the analysis of the number of papers produced in collaboration by the 18 most productive institutions, we could determine the relationships between them all (Table 5). The links tend to be stronger between institutions in a same region or state. Generally, organizations located in neighbour areas present a higher number of coauthored articles. This result corroborates what Katz and Martin (1997) says on the importance of geographical proximity as an incentive to scientific collaboration. 
Rosely Andrade Vargas, Samile Andréa de Souza Vanz, Ida Regina Chittó Stumpf

Having research centers in almost all states of the country, Embrapa presents the highest number of coauthored articles $(3,405)$. The enterprise apparently plays a role of gatekeeper, connecting the various organizations. The strongest collaboration links established by Embrapa - in terms of coauthored articles - involve USP, Universidade Federal de Viçosa (UFV), UNESP and Universidade Federal de Lavras (UFLA). These are the four Brazilian universities that present the greatest number of graduate programs in the field of agricultural sciences.

USP, in turn, has strongest connections with UNESP. Together these two universities published 823 articles in agricultural sciences indexed in WoS between 2000 and 2011. Embrapa, APTA and UNICAMP follow immediately as main partners. As to UNESP, besides USP, its most intensive cooperative relations are established with Embrapa, APTA, and Universidade Estadual de Campinas (UNICAMP).

The high rates of collaboration between institutions in the State of São Paulo is a result of public policies that promote collaborative networks by funding projects that involve research groups of distinct universities and institutes in both the state and the country. This is the case, for instance, of technological innovation programs as Biota, Cepid, ConSITtec and Genoma (FUNDAÇÃO DE AMPARO..., 2005).

The collaborative links between Universidade Federal do Rio Grande do Sul (UFRGS) and Universidade Federal de Santa Maria (UFSM) in agricultural sciences resulted in 243 coauthored articles indexed in WoS between 2000 and 2011. These two universities of the State of Rio Grande do Sul (RS) have significant partnership with Embrapa, which has four units in RS - Wheat, Grape and Wine, Livestock-South and Temperate Climate - and also with two universities in the State of São Paulo - USP and UNESP. Among other collaborative activities, UFRGS, UFSM and Embrapa, together with other institutions in RS, such as Universidade de Passo Fundo (UPF) and Emater, develop researches on soybean pest control (EMPRESA BRASILEIRA..., 2013).

In the State of Paraná, it seems that geographical proximity had no influence at all on collaborative activity between Universidade Federal do Paraná 
(UFPR) and Universidade Estadual de Maringá (UEM) with regard to agricultural research. Although both universities keep important connections with UNESP, USP and Embrapa, the number of articles in the area coauthored by the two institutions from 2000 to 2011 was relatively small: 41 papers, according to the coauthorship criteria. Conversely, the partnership between UEM and Universidade Estadual de Londrina (UEL), both state universities, resulted in about fifty coauthored papers.

In the Federal District (FD), the strong relationship between Universidade de Brasília (UNB) and Embrapa, expressed in 248 coauthored articles, probably results from the nine units of the agricultural research enterprise concentrated in the FD: Cerrados, Vegetables, Plant Genetic Resources and Biotechnology, Agroenergy, Coffee, Technological Information, Products and Market, Studies and Training, and Vegetable Quarantine (EMPRESA BRASILEIRA..., 2013).

The Universidade Federal Rural de Pernambuco (UFRPE), which shares 422 articles with other institutions of the broad national network of agricultural sciences, holds relationships mainly with Embrapa, which has a research unit in the semi-arid region of the State of Pernambuco, USP, UFV and UNESP. As to the relationships maintained by Universidade Federal do Ceará (UFC), the closest ones are with Embrapa, UFV and USP.

In Rio de Janeiro, both the Universidade Federal Rural do Rio de Janeiro (UFRRJ) and Universidade Federal do Rio de Janeiro (UFRJ) are connected with Embrapa through the latter's two research units in the State: Agroindustry and Food and Soil Science. The collaborative relations between Embrapa and the universities has been investigated by Lima, Velho and Faria (2010), who affirm that geographical proximity probably make that universities contribute with Doctors, Masters and students to comprise the research staff of Embrapa Solos, thus creating an intensive flow of interinstitutional collaboration. The soil science research network of Rio de Janeiro is also composed by UFV, UFLA and USP, as well as by foreign partners such as the United States Department of Agriculture (USDA) and the University of Limerick, of Ireland (LIMA; VELHO; FARIA, 2010). 

bibliometric study of scientific output and collaboration

Rosely Andrade Vargas, Samile Andréa de Souza Vanz, Ida Regina Chittó Stumpf

Regarding international collaboration, a regression was observed. Among the 45,163 articles analyzed, there were 7,784 papers $(17,2 \%$ of the total) coauthored by Brazilian scientists and colleagues in foreign countries. The number of 336 publications involving international collaboration in 2000 rose to 1,060 papers in 2011. In percentage terms, however, this kind of scientific collaboration decreased. In 2000, 21.7\% of Brazilian agricultural sciences papers indexed in WoS involved international collaboration. In 2011, this percentage dropped to $15.4 \%$ (Figure 4).

Figure 4 - Percentage of Brazilian papers in agricultural sciences involving international collaboration indexed in WoS, 2000-2011

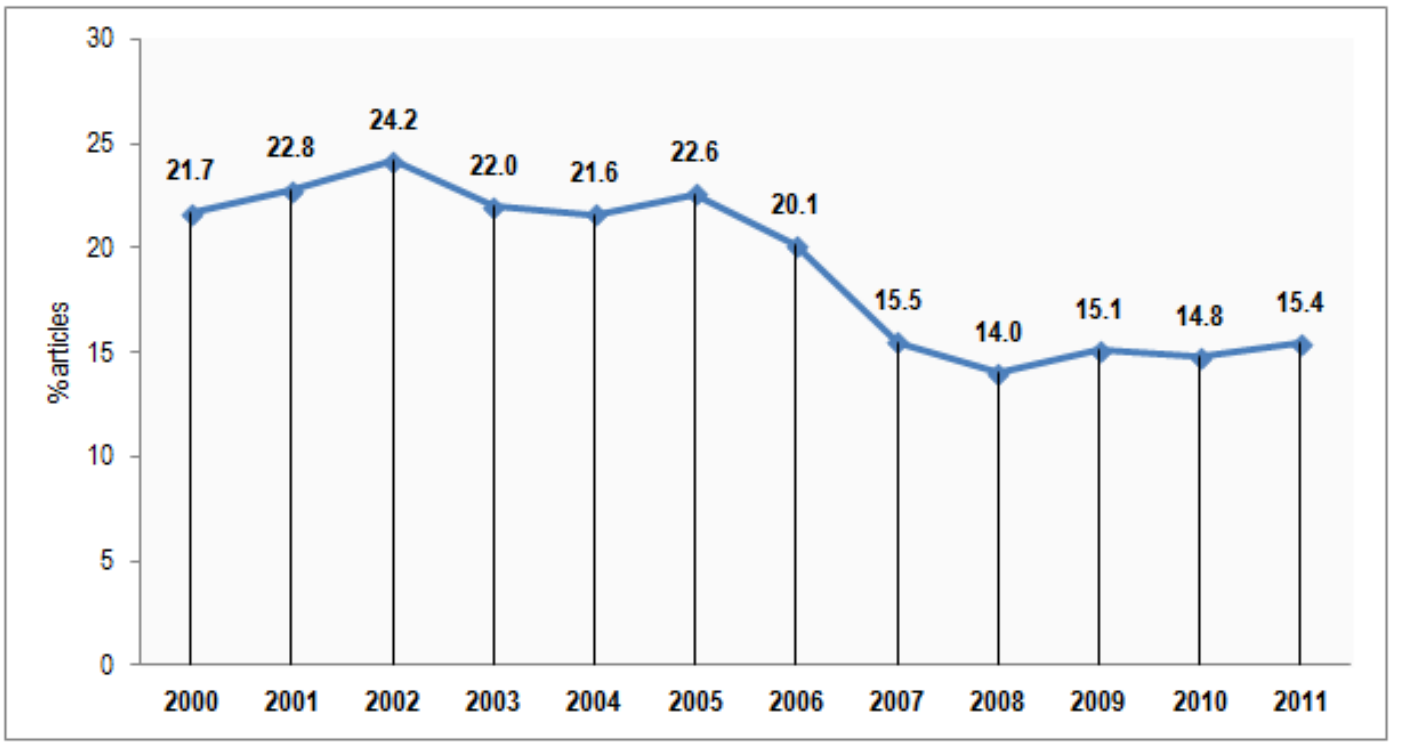

Source: research data.

The greatest rate of scientific international collaboration was registered in 2002 (24.2\%), when the Conselho Nacional de Desenvolvimento Científico e Tecnológico $(\mathrm{CNPq})$ raised the number of post doctoral scholarships $(\mathrm{CNPq}$, 2013). The lowest rate (14.0\%) was observed in 2008, when there was a significant increase in the number of Brazilian journals indexed in WoS, as seen in figure 4 .

This declining tendency in international scientific collaboration, measured through publications indexed in WoS, considering all knowledge fields, is observed since the 1990s. The expansion and consolidation of graduate educa- 
tion in Brazil, the decrease in the number of scholarships for studies abroad and the increase of S\&T investments in the country are some of the likely causes of such reduction (VIOTTI; MACEDO, 2003; FUNDAÇÃO DE AMPARO..., 2005). The recent growth in the collection of Brazilian periodicals in the database may have intensified such tendency. While contributing to raise the number of national articles in WoS, this growth led to the concentration of articles in Brazilian journals, edited mainly in Portuguese, and having lower international visibility (LETA, 2012).

By analyzing the collaboration networks of Brazilian science, between 2004 and 2006, using WoS as source, Vanz and Stumpf (2012) observed a percentual decrease of international collaboration in the publications of the country, both in the agricultural sciences and in other fields. Science development in Brazil takes a path opposed to that of science worldwide, in which international collaboration increases at a faster pace than the collaboration between institutions of a same country. Similarly, by researching the worldwide scientific output in the field of Agronomy, indexed in WoS between 1997 and 2011, CañasGuerrero et al. (2013) observed a high growth in Brazilian publications, especially at the end of the 2000s. However, according to these authors, the output was concentrated in Brazilian journals and presented low levels of international collaboration.

The analyzed Brazilian articles involving international coauthorship revealed cooperative relationships with 128 countries of America, Europe, Asia, Africa and Oceania. Within these publications, 61.4\% involved two countries, and for $22.8 \%$ three countries took part. Articles comprising coauthorship of four and more countries accounted for the remaining $15.8 \%$.

The United States, a traditional partner of Brazil in S\&T issues, was the country with most connections as illustrated in the network of figure 5. The articles of Brazilian researchers coauthored with American partners totaled 2,941, representing $37.78 \%$ of all examined papers involving international collaboration. As to European countries, the most frequent collaborations occurred with France (736 papers, representing 9.4\% of international collaboration), Germany (611 papers, 7.8\%), the United Kingdom (610 papers, 7.8\%) and Spain (486 
Brazilian agricultural research in the Web of Science: a bibliometric study of scientific output and collaboration (2000-2011)

Rosely Andrade Vargas, Samile Andréa de Souza Vanz, Ida Regina Chittó Stumpf

papers, 6.2\%). In South America, the most significant relationships were established with Argentina (514 papers, 6.6\%) and Colombia (200 papers, 2.5\%). It is also worth mentioning the collaborations with Australia (204 papers, 2.6\%) and Japan (191 papers, 2.4\%).

Figure 5 - Brazil's main partner countries in agricultural sciences coauthored publications indexed in WoS, 2000-2011

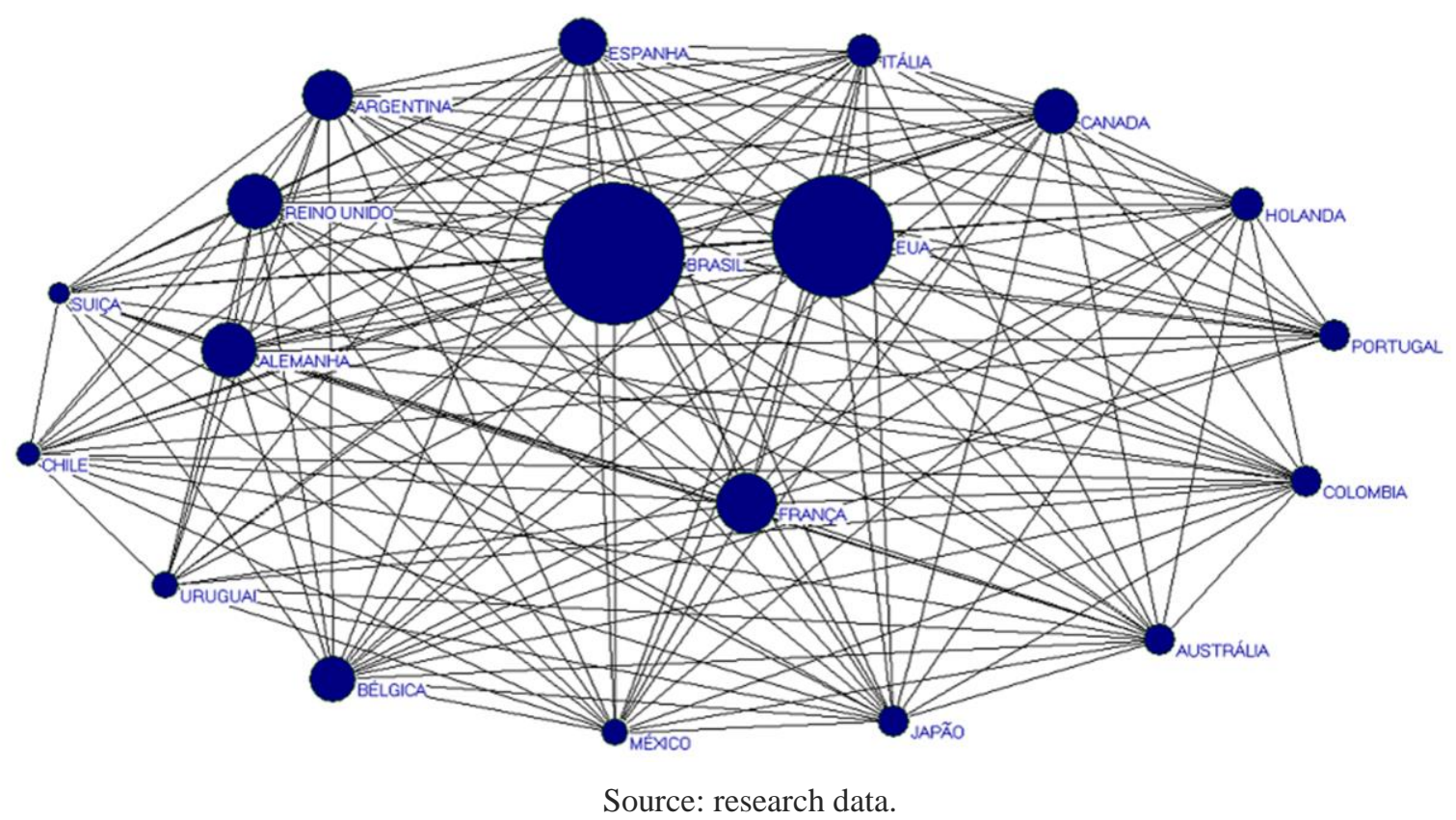

The collaborative links maintained by Brazil with USA and European countries such as France and Germany are facilitated by the existence of scientific cooperation agreements and collaborative research support programs. The agreements with the USA are in force since 1950; with France since the end of the 1960s; and with Germany since the 1990s (FUNDAÇÃO DE AMPARO..., 2005). In addition to these governmental agreements, in recent years, national institutions such as Embrapa, Fundação de Amparo à Pesquisa do Estado de São Paulo (Fapesp) and Fundação de Amparo à Pesquisa do Estado do Rio Grande do Sul (Fapergs) set up cooperation agreements with foreign centers such as the USDA and the Centre de Coopération Internationale en Recherche 
Agronomique pour le Développement (Cirad) of France, and also with universities of the USA and Europe, such as the University of Florida.

\section{Conclusion}

The limited number of publications produced through international collaboration can be pointed out as the weakness of Brazilian scientific output in the area of agricultural sciences indexed in WoS between 2000 and 2011. As previously mentioned, since the 1990s the scientific collaboration of Brazil with other countries, measured in terms of internationally coauthored papers indexed in WoS, has been decreasing in several science fields. Both the expansion and consolidation of graduate programs and the increased investments of the country in science and technology can be pointed as catalysts for this downfall.

On the other hand, the significant growth in the number of Brazilian articles and equally of articles produced in coauthorship both between researchers and between institutions throughout Brazil stands out as a strength. These advances happened within a context characterized by the expansion of graduate courses in the area, by the increasing numbers of Doctors and Masters graduated from these courses and by the increase in scientific output. Furthermore, a process of publishing improvement was observed among the Brazilian scientific journals recently added to WoS. Many journals increased the number of issues published each year following their entry in the database. Therewith, researchers in the country have gained further space for publishing their works.

\section{References}

ADAMS, J.; PENDLEBURY, D.; STEMBRIDGE, B. Building bricks. Exploring the global research and innovation impact of Brazil, Russia, India, China and South

Korea. Thomson Reuters: Philadelphia, 2013. 

bibliometric study of scientific output and collaboration (2000-2011)

Rosely Andrade Vargas, Samile Andréa de Souza Vanz, Ida Regina Chittó Stumpf

ADAMS, J; KING, C. Global research report: Brazil. Research and collaboration in the new geography of science. Leeds: Thomson Reuters, 2009.

ARVANITIS, Rigas; CHATELIN, Yvon. Bibliometrics of tropical soil sciences: Some reflections and orientations. In: McDONALD, Peter. The literature of soil science. Ithaca: Cornell University, 1984. p. 73-94.

BORDONS, María; GÓMEZ, Isabel. Collaboration networkd in science. In: CRONIN, Blaize; ATKINS, Helen Barsky (Eds.). The Web of Knowledge: a festschrift in honor of Eugene Garfield. New Jersey: ASIS, 2000. p. 197-214.

CAÑAS-GUERRERO, I. et al. Bibliometric analysis of research activity in the “Agronomy" category from the Web of Science, 1997-2011. European Journal of Agronomy, Amsterdam, n. 50, p. 19-28, 2013.

CRUZ, C. H. B.; CHAIMOVICH, H. In: UNITED NATIONS Educational, Scientific and Cultural Organization. Unesco science report 2010: the current status of science around the world. Paris: Unesco, 2010. p. 103-122

EMPRESA BRASILEIRA de Pesquisa Agropecuária. [Portal Embrapa]. 2013. Disponível em: <https://www.embrapa.br/>. Acesso em: 2 jan. 2013.

FUNDAÇÃO DE AMPARO à Pesquisa do Estado de São Paulo. Indicadores de Ciência, Tecnologia e Inovação em São Paulo 2010. São Paulo: FAPESP, 2011. Disponível em: 〈http://www.fapesp.br/6479>. Acesso em: 2 jan. 2013.

FUNDAÇÃO DE AMPARO à Pesquisa do Estado de São Paulo. Indicadores de ciência, tecnologia e inovação em São Paulo 2004. São Paulo: FAPESP, 2005. Disponível em: 〈http://www.fapesp.br/2060〉. Acesso em: 2 jan. 2013.

GEOCAPES. Dados estatísticos. 2013. Disponível em: <http://geocapes.capes.gov.br/geocapesds/>. Acesso em: 2 jan. 2014. 
Rosely Andrade Vargas, Samile Andréa de Souza Vanz, Ida Regina Chittó Stumpf

GLÄNZEL, W.; LETA, J.; THIJS, B. Science in Brazil. Part 1: a macro-level comparative study. Scientometrics, Amsterdam, v. 67, n.1, p. 67-86, 2006.

JOURNAL CITATION REPORTS. 2012 JCR Science Edition. [S.1.]: Thomson Reuters, c2013.

KATZ, J. Sylvan; MARTIN, Ben R. What is research collaboration? Research Policy, Amsterdam, v. 26, n. 1, p. 1-18, march 1997.

LEITE, P.; LETA, J.; MUGNAINI, R. A new indicator for international visibility: exploring Brazilian scientific community. Scientometrics, Amsterdam, v. 88, n. 1, p. 311319, 2011.

LETA, J. Brazilian growth in the mainstream science: the role of human resources and national journals. Journal of Scientometric Research, Mumbai, n. 1, p. 44-52, 2012.

LETA, Jacqueline; CHAIMOVICH, Hernan. Recognition and international collaboration: the Brazilian case. Scientometrics, Amsterdam, v. 53, n. 3, p. 325-335, 2002.

LETA, Jacqueline; THIJS, Bart; GLÄNZEL, Wolfgang. A macro-level study of science in Brazil: seven years later. Encontros Bibli, Florianópolis, v. 18, n. 36, p. 51-66, jan./ abr., 2013.

LIMA, Ricardo Arcanjo de; VELHO, Lea Maria Leme Strini; FARIA, Leandro Innocentini Lopes de. Análise bibliométrica da atividade científica da Embrapa Solos (19752009). Boletim de Pesquisa e Desenvolvimento, Rio de Janeiro, v. 153, p. 9-26, 2010. Disponível em: $<$ http://ainfo.cnptia.embrapa.br/digital/bitstream/item/33162/1/Bol-PD153.pdf >. Acesso em: 08 out. 2015.

LUUKKONEN, Terttu; PERSSON, Olle; SIVERTSEN, Gunnar. Understanding patterns of international scientific collaboration. Science, Technology \& Human Values, Thousand Oaks, v. 17, n.1, winter 1992, p. 101-126.

LYRA, Tania Maria de Paula; GUIMARÃES, Jorge Almeida. Produção Científica brasileira em comparação com o desempenho mundial em Ciências Agrárias. Planejamen- 

bibliometric study of scientific output and collaboration (2000-2011)

Rosely Andrade Vargas, Samile Andréa de Souza Vanz, Ida Regina Chittó Stumpf

to e Políticas Públicas, Brasília, v. 30, p. 5-15, 2007. Disponível em:

$\langle$ www.equalis.com.br/biblioteca_online/download_pdf.php?artigo=28 > . Acesso em: 20 jun. 2012.

MEADOWS, J. Comunicação científica. Brasília: Briquet de Lemos, 1999.

MEIS, L.; ARRUDA, A.P.; GUIMARÃES, J. The impact of science in Brazil. IUBMB Life, London, n. 59, p. 227-34, 2007.

MENEGHINI, R. The key role of collaborative work in the growth of Brazilian science in the last ten years. Scientometrics, Amsterdam, v. 35, n. 3, p. 367-373, 1996.

MENEGHINI, R.; PACKER, A. L. Is there science beyond English? Initiatives to increase the quality and visibility of non-English publications might help to break down language barriers in scientific communication. EMBO Reports, Heidelberg, n. 8, p. 112-116, 2007.

MINISTÉRIO da Ciência e Tecnologia. Indicadores nacionais. Disponível em: $<$ http://www.mct.gov.br/index.php/content/view/740.html?execview=>. Acesso em: 1 maio 2014.

PACKER, Abel L. Os periódicos brasileiros e a comunicação da pesquisa nacional. Revista USP, São Paulo, v. 89, p. 24-61, 2011.

TARGINO, M.G., GARCIA, J.C.R. Ciência brasileira na base de dados do Institute for Scientific Information (ISI). Ciência da Informação, Brasília, n. 29, p. 103-17, 2000.

TESTA, J. The globalization of Web of Science, 2005-2010. Philadelphia: Thomson Reuters, 2011. Disponível em: 〈http://wokinfo.com/media/pdf/globalwos-essay.pdf〉. Acesso em: 14 jul. 2012.

VAN LEEUWEN, T. N. et al. Language biases in the coverage of the Science Citation Index and its consequences for international comparisons of national research performance. Scientometrics, Amsterdam, v. 51, n. 1, p. 335-346, 2001. 

bibliometric study of scientific output and collaboration (2000-2011)

Rosely Andrade Vargas, Samile Andréa de Souza Vanz, Ida Regina Chittó Stumpf

VANZ, S. A. S.; STUMPF, I. R. C. Scientific output indicators and scientific collaboration network mapping in Brazil. Collnet Journal of Scientometrics and Information Management, New Delhi, n. 6, p. 1-20, 2012.

VARGAS, R. A.; VANZ, S. A. A; STUMPF, I. R.C. The role of National journals on the rise in Brazilian Agricultural Science Publications in Web of Science. Journal of Scientometric Research, Mumbai, v. 3, n. 1, p. 28-36, 2014.

VELHO, L. M. The 'meaning' of citation in the context of a scientifically peripheral country. Scientometrics, Amsterdam, v. 9, n. 1-2, p. 71-89, 1986.

VELLOSO, A.; LANNES, D.; MEIS, L. Concentration of science in Brazilian governamental universities. Scientometrics, Amsterdam, v. 61, n. 2, p. 207-220, 2004.

VIOTTI, E. B.; MACEDO, M. Indicadores de Ciência, Tecnologia e Inovação no Brasil. Campinas: UNICAMP, 2003.

\section{A pesquisa brasileira em Ciências Agrárias na Web of Science: estudo bibliométrico da produção científica e colaboração (2000- 2011)}

Resumo: Este trabalho apresenta uma análise da produção e colaboração científica das Ciências Agrárias brasileira na Web of Science (WoS) no período 20002011. Um total de 45.163 documentos foram recuperados. A análise dos dados foi realizada com o uso dos softwares Bibexcel e Pajek. Os resultados indicaram que o número de artigos brasileiros no campo das Ciências Agrárias indexados na WoS aumentou em 344\%; no entanto, o principal motor para esse crescimento foi o aumento no número de revistas nacionais indexadas na base de dados. Apesar dos artigos brasileiros serem encontrados em 799 periódicos provenientes de 46 países, 53,5\% da produção total foi publicada em periódicos nacionais 
Rosely Andrade Vargas, Samile Andréa de Souza Vanz, Ida Regina Chittó Stumpf

de baixo fator de impacto. A percentagem de artigos com vários autores no volume total de publicações aumentou de 96,1\% em 2000 para 98,4\%, em 2011. A proporção de artigos em colaboração entre as instituições aumentou de 47,3\%, em 2000, para 64,2\%, em 2011. No entanto houve uma diminuição da porcentagem de publicações com colaboração internacional de 21,7\% em 2000 para 15,4\% em 2011. As relações de colaboração mais importantes foram estabelecidos com os EUA, a França e a Alemanha.

Palavras-chave: Ciência brasileira. Ciências Agrárias. Bibliometria. Produção científica. Colaboração científica.

\section{Agradecimentos}

Authors thank the funding from CAPES and CNPq for the development of this research.

Recebido em 08/09/2015

Aceito em 02/12/2015 